Article

\title{
Do Dominant Ants Affect Secondary Productivity, Behavior and Diversity in a Guild of Woodland Ants?
}

\author{
Jean-Philippe Lessard ${ }^{1,2, * \mathbb{D}}$, Katharine L. Stuble ${ }^{1,3}$ and Nathan J. Sanders ${ }^{1,4}$ \\ 1 Department of Ecology and Evolutionary Biology, University of Tennessee, Knoxville, TN 37996, USA; \\ kstuble@holdenfg.org (K.L.S.); njsander@umich.edu (N.J.S.) \\ 2 Department of Biology, Concordia University, Montreal, QC H4B-1R6, Canada \\ 3 The Holden Arboretum, 9500 Sperry Rd, Kirtland, OH 44094, USA \\ 4 Department of Ecology and Evolutionary Biology, University of Michigan, Ann Arbor, MI 48109, USA \\ * Correspondence: jp.lessard@concordia.ca; Tel.: +1-514-848-2424 (ext. 5184)
}

Received: 23 October 2020; Accepted: 29 November 2020; Published: 2 December 2020

check for updates

\begin{abstract}
The degree to which competition by dominant species shapes ecological communities remains a largely unresolved debate. In ants, unimodal dominance-richness relationships are common and suggest that dominant species, when very abundant, competitively exclude non-dominant species. However, few studies have investigated the underlying mechanisms by which dominant ants might affect coexistence and the maintenance of species richness. In this study, we first examined the relationship between the richness of non-dominant ant species and the abundance of a dominant ant species, Formica subsericea, among forest ant assemblages in the eastern US. This relationship was hump-shaped or not significant depending on the inclusion or exclusion of an influential observation. Moreover, we found only limited evidence that $F$. subsericea negatively affects the productivity or behavior of non-dominant ant species. For example, at the colony-level, the size and productivity of colonies of non-dominant ant species were not different when they were in close proximity to dominant ant nests than when they were away and, in fact, was associated with increased productivity in one species. Additionally, the number of foraging workers of only one non-dominant ant species was lower at food sources near than far from dominant $F$. subsericea nests, while the number of foragers of other species was not negatively affected. However, foraging activity of the non-dominant ant species was greater at night when $F$. subsericea was inactive, suggesting a potential mechanism by which some non-dominant species avoid interactions with competitively superior species. Gaining a mechanistic understanding of how patterns of community structure arise requires linking processes from colonies to communities. Our study suggests the negative effects of dominant ant species on non-dominant species may be offset by mechanisms promoting coexistence.
\end{abstract}

Keywords: behavioral interactions; coexistence; co-occurrence; competitive exclusion; dominance; Formicidae; scale

\section{Introduction}

Dominant species are those species that excel at exploiting and sequestering resources [1] thereby affecting the behavior and population dynamics of other species and potentially the structure of communities. Janzen [2] and Connell [3] famously argued that if populations of dominant species were not kept in check by predators or parasites, they would become overabundant and exclude other species, leading to a decrease in species richness. In relation to this hypothesis, several studies have documented a unimodal relationship between the richness of species in a local community and the abundance of dominant species $[4,5]$. The most common explanation for this unimodal relationship is that at low levels of dominance, the abundance of both dominant and non-dominant ants increases as 
environmental stress decreases. Then, as dominant species become more abundant, they competitively exclude non-dominant species leading to the descending portion of the hump-shaped curve $[4,5]$. An alternative explanation is that the abundance of dominant and non-dominant species peaks at a different point along the abiotic stress gradient. One approach for teasing apart these alternative explanations is to test predictions regarding the influence of competition with a dominant species across levels of organization, from individuals to entire communities.

In animals, dominant species are those with high abundance and biomass, which may be attained through exploitative and interference competition. Dominance can be attained via exploitative competition or interference competition. In ants, dominant species often display aggressive behavior enabling them to defend territories and monopolize food resources. Aside from the unimodal relationship between species richness and the abundance of dominant species [4,5], evidence that dominant species have community-wide effects on other species includes the effects of competitively dominant exotic species on the diversity [6-9], spatial arrangement [10] and phylogenetic structure of native ant communities [11]. Additional evidence stems from the effects dominant ants have on patterns of co-occurrence in arboreal assemblages of the tropics [12-17] and the dominance-species richness relationship $[4,5,18,19]$. However, a recent global study suggests that exotic dominant ants are more likely to exert community-wide effects than are native dominant ants [20]. Moreover, experimental removals of dominant species have yielded mixed results [21-23]. In sum, whether or not native dominant ants affect other members of the community deserves further exploration.

Several studies have documented the effects of dominant ant species on the behavior, resource use and fitness of non-dominant ant colonies [24-28], while others have documented their effects on community structure $[4,18,29-33]$. Examining the outcome of interspecific interactions across organization levels is key to elucidating the mechanism by which competition might shape community structure [34]. However, few studies $[22,23,33]$ have linked the effects of a single dominant ant species on individual colonies, populations or communities of competitively inferior ants. In ants, community-level effects, relate to the richness or other multi-species metrics of diversity (including composition). Population-level effects relate to the abundance of a species at a site (i.e., number of colonies or workers). Individual effects relate to characteristics of the colonies of a given species. Worker-level effects relate to the behavior of individual ant workers when confronted with workers of another species at a given food source.

Community-level effects of dominant ants on non-dominant ant species are well documented but much less is known regarding the individual-level effects (i.e., colony-level effects) of dominant ants on non-dominant ants. It is well established that dominant ants often interfere with resource exploitation by non-dominant ant workers via negative behavioral effects [8,29,35-38]. Moreover, it is often assumed that by interfering with the foraging activities of non-dominant species, dominant ants also affect rates of resource acquisition and sequestration at the individual colony-level (but see [27]). If that were the case, the effect of dominant ants should be observed at the individual-level by decreasing the productivity, size and/or fitness of colonies of non-dominant ants [26,31]. However, whether the negative effect of dominant species on colony success of non-dominant ants is the rule rather than the exception, and whether colony-level effects always translate into community-level effects, is unclear [39].

Effects of dominant species in the genus Formica (rufa group) on non-dominant ant species have been well documented in a series of seminal studies in ant assemblages in Finland [26-28,32,33]. Formica ants in the rufa group form large colonies and are aggressive but are uncommon in temperate forests of North America. However, Formica ants in the fusca group, which form smaller colonies and are less aggressive, are ubiquitous. Here, we examine how one of the most numerically and behaviorally dominant species in a low-elevation temperate forest in the eastern US, Formica subsericea (fusca group) Say, affects non-dominant ant species. We first investigate community-level effects by testing whether the relationship between the richness of non-dominant species and the abundance of $F$. subsericea best fits a unimodal or linear model $[4,5,18]$. Then, to elucidate whether community-level effects of $F$. subsericea 
concords with individual-level and behavioral effects, we asked the following questions: (i) the colony density and/or abundance of non-dominant ant species decreases with increasing abundance of F. subsericea, (ii) the colony size and/or productivity of colonies of non-dominant ant species is lower near than far from the nest of $F$. subsericea, (iii) resource use by non-dominant ants is lower near than far from F. subsericea nests and (iv) non-dominant ant foraging activity is lower when F. subsericea are active than when inactive.

\section{Materials and Methods}

\subsection{Study Site}

We conducted this study in a mid-elevation ( $740 \mathrm{~m}$ elevation) forest in the southern Appalachian mountain range, within Great Smoky Mountains National Park ( $35^{\circ} 38^{\prime} 41^{\prime \prime}$ N, 83 $35^{\prime} 06^{\prime \prime}$ W) in June-August 2008 and 2009. Dominant overstory vegetation included Liriodendron tulipifera, Halesia tetraptera var. monticola, Tilia americana var. heterophylla, Acer rubrum, Magnolia acuminata and Fraxinus americana. Dominant understory vegetation included Acer pensylvanicum, Calycanthus floridus and Rhododendron maximum. Formica subsericea Say is common in open and partially open woodlands and forest ecotones of eastern North American temperate forests [40]. Nests of $F$. subsericea are usually deep and the nest entrance is often in a dead log or adjacent to large stones. In the absence of a log or rock, F. subsericea often forms small mounds covered by leaf-litter around the nest entrance.

In temperate forests of eastern North America, F. subsericea is one of several locally dominant species [29,41]. Although colony size and rates of aggression by F. subsericea are low relative to dominant species found in arid and tropical systems. In this particular part of the National Park, the density of $F$. susbericea colonies is higher than anywhere else in the region [42-44] and therefore, its presence likely affects other species. Workers of $F$. subsericea do not maintain exclusive foraging territories (i.e., absolute territories) but do aggressively defend their nest and food. Typically, workers of $F$. subsericea rapidly recruit to food resources, displace other species and monopolize the resource. Workers of Camponotus pennsylvanicus sometimes manage to displace $F$. subsericea from food resources but this depends on the distance of the food resource from the F. subsericea nest and the size of the F. subsericea colony (J.-P. Lessard pers. obs.). However, because C. pennsylvanicus was not common at the study plots we worked in, we did not consider it dominant [45]. In our study plots, the mean distance between a focal nest of $F$. subsericea and the nearest $F$. subsericea neighbor nest was $10.25 \pm 3.15 \mathrm{~m}$, which roughly corresponds to the average radius of a F. subsericea foraging territory in the studied sites (foraging territories are usually asymmetrical in shape).

\subsection{Sampling}

Though the density of $F$. subsericea is high in this region [42-44], there was considerable among-site variation. We took advantage of this natural variation in the density of $F$. subsericea to examine the potential effects of this species on community and population-level effects, as well as on behavior. Though this is a commonly used approach in studies of dominance on ant community structure $[4,5,18,46]$, we acknowledge that it is correlative only and a long-term removal experiment would provide additional insights. Here, we located 10 sites separated by at least $50 \mathrm{~m}$. Each site was $300 \mathrm{~m}^{2}$ and had 12 sampling stations arranged in a $3 \times 4$ grid and separated by $10 \mathrm{~m}$. At each site we surveyed ants using baits and pitfall traps during peak ant activity (June-July) in both 2008 and 2009. Within these 10 sites we also located 16 nests of $F$. subsericea, which were later used for colony-level tests of dominance effects. To assess the colony-level effects of $F$. subsericea on non-dominant species, we compared behavioral and colony traits near and far from F. subsericea nests.

\subsubsection{Community and Population-Level Effects}

To estimate the relative abundance of ant species in our system, we placed pitfall traps at each of the 12 sampling stations at the 10 sites within 1 meter of the bait station. Pitfall traps are commonly 
used to estimate the relative abundance of ants $[4,5,18,35,47]$. We set up pitfall traps $24 \mathrm{~h}$ after the last baiting trial. Each pitfall trap ( $55 \mathrm{~mm}$ diameter, $75 \mathrm{~mm}$ deep) was partially filled with propylene glycol (low toxicity antifreeze), buried flush with the ground and left in place for $72 \mathrm{~h}$. All ants were counted, identified to species and deposited in NJ Sanders's personal collection.

Here, we used the total number of pitfall traps in which a species occurred (i.e., incidence) as an estimate of its abundance for that site since worker incidence and the number of workers were strongly correlated $\left(R^{2}=0.95\right)$ [48-50]. Pitfall trap incidence is a more conservative approach to estimate the abundance of ant colonies and has been used in previous studies with temperate forests ant assemblages [48,51].

\subsubsection{Individual-Level Effects}

By setting up observation grids around F. subsericea nests we found that activity levels of F. subsericea workers is $3 \times$ higher within $1 \mathrm{~m}$ of the nest entrance than anywhere else within a $10 \mathrm{~m}$ radius (unpublished data). Thus, to test whether F. subsericea affected the size and productivity of colonies of non-dominant ants, we collected entire colonies of the two most abundant non-dominant species on baits-Aphaenogaster rudis and Nylanderia faisonensis-near $(\leq 1 \mathrm{~m})$ and far $(5-10 \mathrm{~m})$ from 16 F. subsericea nests. Colonies of $A$. rudis in this system are typically monodomous (i.e., occupy only one nest) and monogynous (i.e., only one queen is present in the colony), although in some instances 2-3 queens were found in a colony [52]. Colonies of N. faisonensis in our system appeared to all be monodomous but others have found polydomous colonies of that species [53]. All colonies of N. faisonensis were monogynous, which is consistent with previous records for that species [53].

Both $A$. rudis and $N$. faisonensis frequently interacted with F. subsericea on baits and their colonies are conspicuous and relatively easy to collect. Another non-dominant ant species, Myrmica punctiventris, was also abundant on baits and frequently interacted with $F$. subsericea but we were unable to locate enough colonies of $M$. punctiventris for statistical analyses. For each of these species, we attempted to collect one $A$. rudis and one $N$. faisonensis colony near and one colony of each species far from each of the 16 F. subsericea nests. Colonies were typically found in dead branches and leaf litter. Dead branches were moved directly into a large plastic container with edges coated in Teflon, while making sure to capture any workers/queens attempting to escape. When in the leaf litter, a shovel was used to collect the leaf litter as well as $15-20 \mathrm{~cm}$ of soil underneath it, while making sure to capture any escaping individuals and visually inspecting surrounding leaf litter. We were able to locate $24 \mathrm{~A}$. rudis colonies $($ near $=12$, far $=12$ ) and $14 N$. faisonensis colonies (near $=8$, far $=6$ ). Colonies were collected during the last 2 weeks of July 2008. For each colony, we counted the number of brood, workers and queens. Due to the size and quantity of $N$. faisonensis eggs, it was impossible to accurately estimate the number of eggs in the colonies sampled. Colony size was calculated as the total number of workers in a colony and colony productivity was calculated as the proportion of brood to workers in a colony [54,55].

\subsubsection{Worker-Level Effects}

We placed bait stations near $(\leq 1 \mathrm{~m})$ and far $(5-10 \mathrm{~m})$ from 12 focal F. subsericea nests. Baiting stations consisted of 4 laminated index cards arranged in a square, with $10 \mathrm{~cm}$ between each card. We used cotton balls dipped into a sugar-water solution on two of the baits and cat food on the other two. We operated the baits both between 1:00 p.m. and 5:00 p.m., and, on the same day, between 9:00 p.m. and 1:00 a.m. At night, we used a red-light headlamp to avoid interfering with ant foraging activities [56-58]. We visited baits every hour for three hours. Baiting was not conducted on days with heavy precipitation. At each bait station we tallied (1) the number of workers from the three most common non-dominant ants on baits (i.e., A. rudis, N. faisonensis and M. punctiventris), (2) the total abundance of non-dominant workers (i.e., all ants other than F. subsericea) and (3) the total species richness of non-dominant species. For each $F$. subsericea nest, we pooled observations from the 4 baits and all three observational visits to get a single value for each of the parameters listed above both near and far from each $F$. subsericea colony. 


\subsection{Estimating Dominance}

We used baits to quantify the outcome of behavioral interactions and the relative abundance of ant species at food resources, a common technique in studies of ant ecology $[28,29,31,35,47,59,60]$. Baits consisted of $5 \mathrm{~g}$ of cat food (11\% protein, $4 \%$ fat, $78 \%$ water) on a white laminated index cards positioned on the ground. Cat food is a useful resource for baiting for ants because it can be retrieved both in liquid and solid form and contains a mix of protein, lipids and salts. It has been used in several community-level studies with ants to assess behavioral dominance and species richness $[4,61,62]$. In our study system, all of the ant species that were recorded on sugar-based baits were also recorded on cat food baits. At each of the 10 sites, we placed baits at the 12 sampling stations and recorded the number of workers of each species as well as any interspecific behavioral interactions. We visited each bait station for $1 \mathrm{~min}$ every $15 \mathrm{~min}$ for $3 \mathrm{~h}$ and visited each of the 10 sites once (for a total of 1440 censuses). One of us (JPL) conducted all of the baiting trials on sunny or partially sunny days between 1:00 p.m. and 5:00 p.m., during peak ant activity [41].

To determine which ant species were dominants, previous studies have used a variety of approaches, from mainly qualitative [63] to a mix of dominance metrics [18,29,47,60]. Because different approaches to estimating dominance can yield different results [60] and because dominance in ants has several components, we used three different approaches for estimating dominance: behavioral dominance, numerical dominance and ecological dominance.

To estimate behavioral dominance, we tallied the number of wins and losses in encounters for each species observed at baits. A win consisted of a species attacking another species (i.e., aggressive behavior) causing the losing ant to leave the bait station (i.e., submissive behavior); the ant that left the bait after such an encounter would in turn get a loss. At any given bait, the outcome of the interaction between two given species was counted only once to insure independence among observations. We then used the Colley ranking method [64] to rank each species from most dominant to most submissive as in Reference [47]. The Colley method estimates the dominance hierarchy based on both the proportion of wins for a species out of the total number of interactions for that species, as well as the relative strength of the opponents in inter-specific interactions. Thus, winning an interaction against a dominant species is worth more than winning against a submissive species. The Colley method was designed to rank intercollegiate American football teams and does not require that every species interact with every other species in order to obtain an accurate ranking of the species in the hierarchy.

We also calculated numerical dominance by estimating the abundance of each species in pitfall traps across all 10 sites [65]. We used the total number of pitfall traps in which a species occurred as an estimate of numerical dominance for that species. We estimated ecological dominance by extrapolating total biomass for each ant species based on known body size and abundance. We used a modified version of the scaling equation presented in Reference [66] so that we could estimate individual worker mass from body size data

$$
\mathrm{M}=\left(4.7297 \times 10^{-4}\right) \mathrm{WL}^{3.179}
$$

in this Equation (1), WL is Weber's Length, which is a commonly used proxy for body size and which we derived from published work [67]. We then estimated the average biomass of ant colonies for each species we caught in pitfall traps by multiplying the predicted mass (M) of workers by the by colony size, where colony size was an average extracted from the literature [67]. Finally, to estimate the total biomass of an ant species at our site, we multiplied the predicted colony biomass by the incidence of that species across all pitfall traps (Table 1).

We ranked each species that was recorded at baits and in pitfall traps according to the three dominance indices described above. We determined that $F$. subsericea was the most dominant because it was the only species to be ranked no lower than 3rd in any dominance hierarchy for any metric for all of the dominance indices (Table 2). Formica subsericea also came out as the most dominant ant species when, for each species, we summed the rank occupied in each of the three hierarchies. 
Table 1. Metrics used to estimate behavioral dominance, numerical dominance and ecological dominance.

\begin{tabular}{|c|c|c|c|c|c|}
\hline \multirow{2}{*}{ Species } & Worker Count & Abundance & Worker Body Size & Predicted Worker Mass & Colony Size \\
\hline & No. of Workers & No. of Incidence & Weber's Length (mm) & (g) & No. of Workers \\
\hline Aphaenogaster fulva Roger & 10 & 3 & 1.48 & 1.64 & 281 \\
\hline Aphaenogaster rudis Enzmann & 712 & 123 & 1.41 & 1.41 & 303 \\
\hline Camponotus americanus Mayr & 3 & 3 & 2.59 & 9.74 & 3560 \\
\hline Camponotus pennsylvanicus (DeGeer) & 20 & 18 & 2.52 & 8.93 & 2222 \\
\hline Formica subsericea Say & 181 & 57 & 2.33 & 6.96 & 8919 \\
\hline Lasius alienus (Förster) & 87 & 19 & 1.42 & 1.44 & 3000 \\
\hline Myrmica punctiventris Roger & 107 & 36 & 1.53 & 1.83 & 86 \\
\hline Nylanderia faisonensis (Forel) & 25 & 18 & 0.61 & 0.10 & 268 \\
\hline Prenolepis imparis (Say) & 8 & 3 & 0.91 & 0.35 & 3370 \\
\hline Temnothorax longispinosus (Roger) & 5 & 4 & 0.62 & 0.10 & 47 \\
\hline
\end{tabular}

Worker count is the sum of all workers and abundance is the sum of all incidences of a given species recorded across all sites (120 pitfall traps). Body size and colony size data were extracted from Reference [67]. Weber's length of mesosoma is a proxy for body size commonly used in ant studies. It is measured as the length separating the anterior edge of pronotum from the posterior corner of metapleuron. Predicted worker mass was calculated based on worker body size estimates and the equation provided in Reference [66]. The dominant species is indicated in bold.

Table 2. List of species recorded both in pitfall trap and on baits in Great Smoky Mountains National Park.

\begin{tabular}{|c|c|c|c|}
\hline \multirow{2}{*}{ Species } & Behavioral Dominance & Numerical Dominance & Total Predicted Biomass (kg) \\
\hline & Colley Ranking & No. of Pitfall Traps & No. Pitfall Traps $\times$ Colony Size $\times$ Worker Biomass \\
\hline Aphaenogaster fulva Roger & $0.71(2)$ & $3(8)$ & $1.39(8)$ \\
\hline Aphaenogaster rudis Enzmann & $0.40(7)$ & $123(1)$ & $52.55(5)$ \\
\hline Camponotus americanus Mayr & $0.68(4)$ & $3(9)$ & 104. $06(3)$ \\
\hline Camponotus pennsylvanicus (DeGeer) & $0.93(1)$ & $18(5)$ & $357.19(2)$ \\
\hline Formica subsericea Say & $0.70(3)$ & $57(2)$ & $3538.74(1)$ \\
\hline Lasius alienus (Förster) & $0.68(5)$ & $19(4)$ & $82.19(4)$ \\
\hline Myrmica punctiventris Roger & $0.40(8)$ & $36(3)$ & $5.66(6)$ \\
\hline Nylanderia faisonensis (Forel) & $0.08(10)$ & $18(6)$ & $0.47(9)$ \\
\hline Prenolepis imparis (Say) & $0.58(6)$ & $3(10)$ & $3.54(7)$ \\
\hline Temnothorax longispinosus (Roger) & $0.20(9)$ & $4(7)$ & $0.02(10)$ \\
\hline
\end{tabular}

Listed are scores for behavioral dominance, numerical dominance and total biomass. For each dominance category, ranks are indicated in parentheses. The most dominant species is indicated in bold. 


\subsection{Statistical Analyses}

We examined the relationship between ant species richness and the incidence of $F$. subsericea. At each site, we estimated the abundance (i.e., incidence) of $F$. subsericea as the number of pitfall traps containing at least one $F$. subsericea worker. Species richness was calculated as the total number of ant species recorded at a site across all pitfall traps (excluding F. subsericea). One data point was a highly influential observation, so we conducted this part of the analyses with and without the outlier. Because it has been suggested that the species richness of non-dominants might be negatively related to the abundance of dominant ants only at high levels of dominance [4,5], we considered whether the relationship between the species richness of non-dominants and abundance of $F$. subsericea was best described by either a linear least squares regression or a polynomial regression. We compared the fit of the models by comparing the adjusted $\mathrm{r}^{2}$ and Akaike information criterion (AIC) values for each fit.

2.4.1. Is the Pooled Abundance of Non-Dominant Species Negatively Related to the Abundance of the Dominant Species?

We estimated the abundance of non-dominant ant species at each of the 10 sites by counting the number of pitfall traps in which each non-dominant ant species was recorded and then pooling the abundance of all non-dominant ants. We then related the abundance of non-dominant species to that of the dominant species using linear regression. We also tested whether the effect of F. subsericea on non-dominant ants differed between common and rare species by pooling the incidence of common (A. rudis, N. faisonensis, M. punctiventris) and less-common species (all other species) separately.

2.4.2. Is the Colony Size and/or Productivity of Non-Dominant Ant Species Negatively Influenced by Proximity to a F. subsericea Colony?

We used paired $t$-tests to determine whether colony size and productivity of $A$. rudis differed between colonies near and far from a focal F. subsericea nests. Because N. faisonensis colonies could not always be paired, we used one-sample $t$-tests to assess whether mean colony size and productivity was higher far from $F$. subsericea nests relative to near. The data were not always normally distributed, thus we used both parametric (i.e., one-sample, two-sample or paired $t$-tests) and non-parametric (i.e., Wilcoxon or Wilcoxon signed rank tests) tests for all colony-level analyses.

\subsubsection{Is Resource Use by Non-Dominant Ants Negatively Influenced by Proximity to a F. subsericea Colony?}

We tested whether the abundance and species richness of non-dominant workers at baits depended on distance from the focal nest using a paired $t$-test and a Wilcoxon signed rank test. We performed analyses separately for day and night baiting sessions. We did not combine the distance and time variables into a single model because the observations were paired.

2.4.4. Are Temporal Patterns of Foraging Activity in Non-Dominant Species Are Negatively Related to Those of F. subsericea?

It is possible that non-dominant species might take advantage of lower foraging activities of F. subsericea at night to exploit resources and avoid interference competition. Thus, we assessed whether foraging activity by non-dominant ants varied between day and night. We estimated differences between diurnal and nocturnal foraging patterns by subtracting the number of workers of non-dominant species recorded during the night from the number recorded during the day. In addition, we estimated temporal variability in the richness of foraging ant species by subtracting the number of species recorded at baits during the night from the number recorded during the day. Depending on the normality of the data, we used one-sample $t$-tests or one-sample Wilcoxon signed rank tests to ask whether the difference between the (1) total abundance of workers and (2) total number of species of non-dominant ants foraging during day and night differed from zero. 


\section{Results}

The incidence of the dominant $F$. subsericea varied from 1 to 8 (of 12) pitfall traps per site. The total abundance of non-dominant species (the sum of incidences across 12 pitfall traps at a given site) varied from 24 to 45 and total richness of non-dominant species varied from 4 to 12 species per site.

\subsection{Species Richness and Dominance}

When considering all sampled sites, there was only a marginally significant polynomial relationship between the abundance of $F$. subsericea and species richness $\left(\mathrm{r}^{2}=0.53, \mathrm{r}^{2}\right.$ adjusted $=0.39, n=10, p=0.07$, AIC $=17.90$ for quadratic fit vs. $\mathrm{r}^{2}=-0.26, \mathrm{r}^{2}$ adjusted $=-0.12, n=10, p=0.95$, AIC $=23.40$ for linear fit; Figure 1). The relationship was significant only if one observation was removed $\left(\mathrm{r}^{2}=0.63\right.$, $\mathrm{r}^{2}$ adjusted $=0.51, n=9, p=0.05$, AIC $=10.36$ for quadratic fit vs. $\mathrm{r}^{2}=0.25, \mathrm{r}^{2}$ adjusted $=0.15, n=9, p=0.16$, $\mathrm{AIC}=14.64$ for linear fit). Note that adjusted $\mathrm{r}^{2}$ values can be negative when the model fits the data poorly [68].

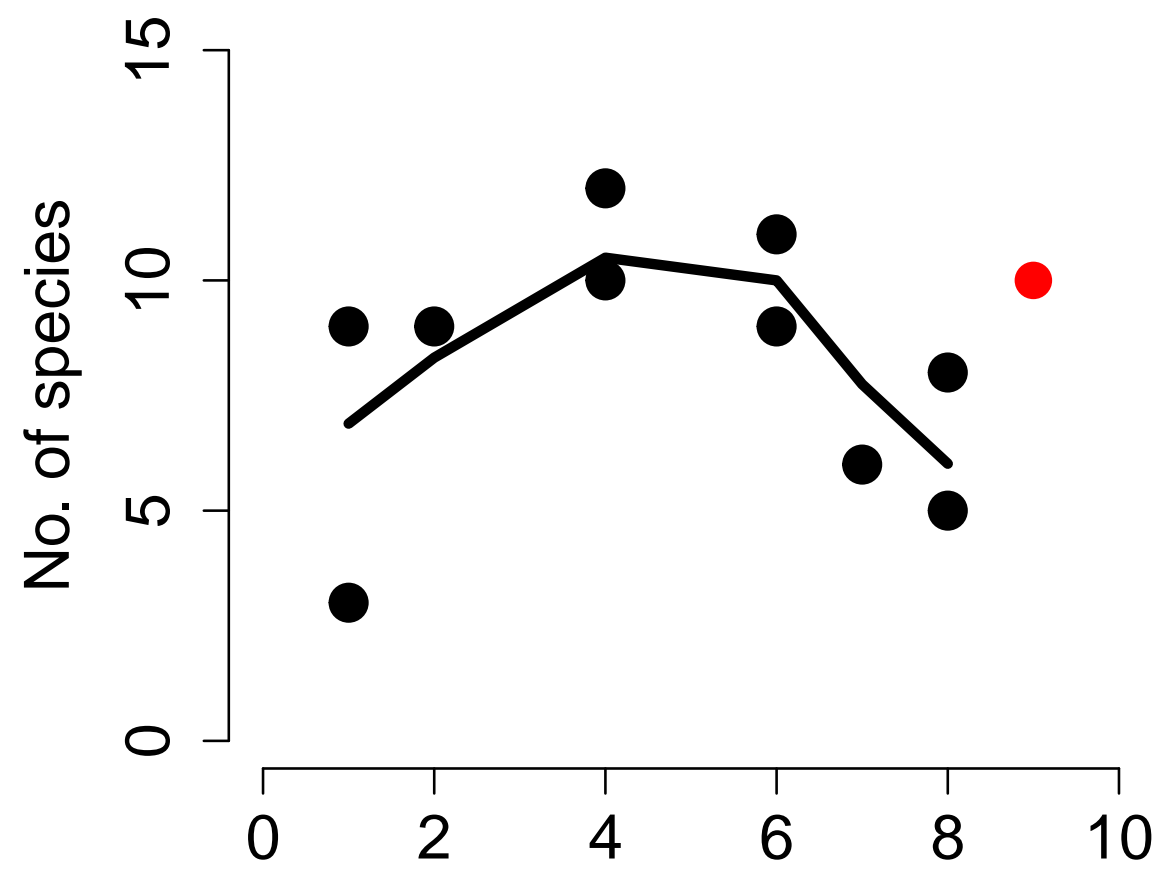

Abundance of F. subsericea

Figure 1. The unimodal relationship between the richness of non-dominant ant species recorded in pitfall traps at a site and the number of pitfall traps in which a dominant $F$. subsericea was recorded.

The relationship is statistically significant only if the outlying point in red is excluded.

\subsection{Is the Pooled Abundance of Non-Dominant Species Negatively Related to the Abundance of the Dominant Species?}

There was no relationship between the abundance of $F$. subsericea and the total abundance (incidences) of non-dominant species $\left(\mathrm{r}^{2}=0.28, \mathrm{r}^{2}\right.$ adjusted $=0.07, n=10, p=0.32$, AIC $=39.77$ for quadratic fit vs. $\mathrm{r}^{2}=0.04, \mathrm{r}^{2}$ adjusted $=-0.07, n=10, p=0.57, \mathrm{AIC}=39.00$ for linear fit). This relationship was not different when the statistical outlier was removed $\left(\mathrm{r}^{2}=0.17, \mathrm{r}^{2}\right.$ adjusted $=-0.10, n=9, p=0.57$, AIC $=30.80$ for quadratic fit vs. $\mathrm{r}^{2}=0.08, \mathrm{r}^{2}$ adjusted $=-0.05, n=9, p=0.47$, AIC $=29.76$ for linear fit). The relationship between the abundance of non-dominant ants and dominant ants did not depend on whether the non-dominant species were common $\left(\mathrm{r}^{2}=0.30, \mathrm{r}^{2}\right.$ adjusted $=0.10, n=10, p=0.29$, AIC $=28.87$ for quadratic fit vs. $\mathrm{r}^{2}=0.30, \mathrm{r}^{2}$ adjusted $=0.21, n=10, p=0.10, \mathrm{AIC}=26.91$ for linear fit $)$ or rare $\left(\mathrm{r}^{2}=0.37\right.$, 
$\mathrm{r}^{2}$ adjusted $=0.19, n=10, p=0.20$, AIC $=27.65$ for quadratic fit vs. $\mathrm{r}^{2}=0.00, \mathrm{r}^{2}$ adjusted $=-0.12, n=10$, $p=0.94, \mathrm{AIC}=30.30$ for linear fit).

3.3. Is Colony Size and/or Productivity of Non-Dominant Ant Species Negatively Influenced by Proximity to a Dominant Ant Colony?

Neither colony size (Figure 2a) nor colony productivity (Figure $2 b$ ) of $A$. rudis depended on distance from F. subsericea nests (Table 3). Likewise, the colony size of $N$. faisonensis did not depend on distance from F. subsericea nests (Figure 2a), whereas productivity was, on average, $2 \times$ higher near than far from F. subsericea nests (Figure 2b), though this result was marginally significant (Table 3).

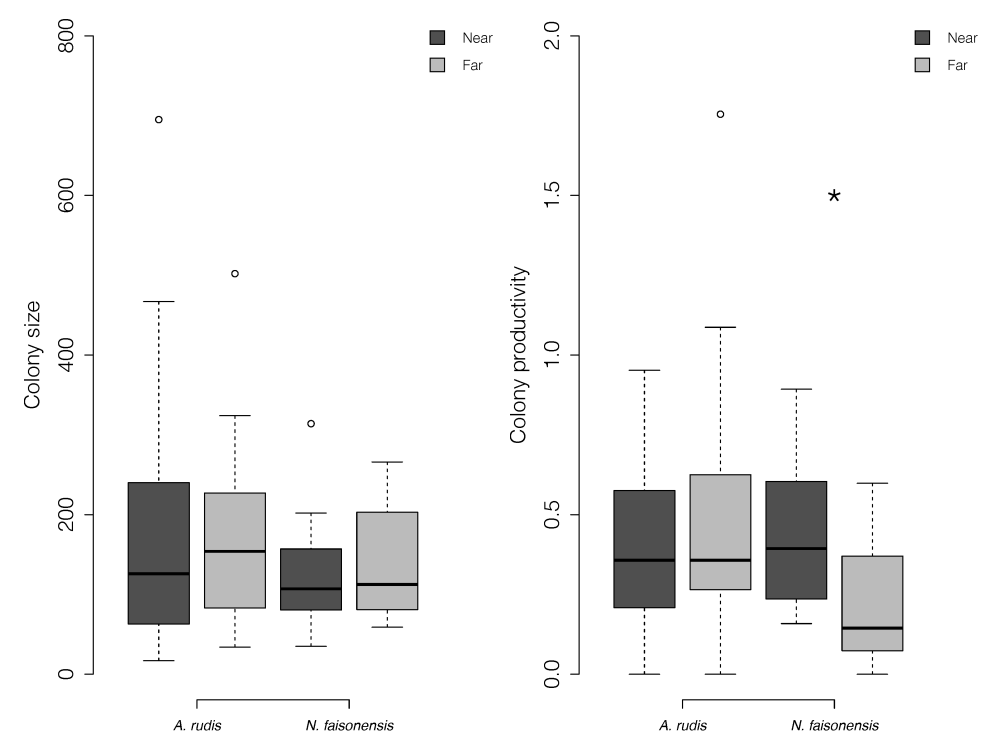

Figure 2. Mean (a) colony size (number of workers) and (b) colony productivity (number of broods/number of workers) of non-dominant ant species A. rudis and N. faisonensis near and far from focal nests of dominant F. subsericea. Asterisks indicate significant differences $(p<0.05)$.

Table 3. Variation in colony size and productivity of colonies of non-dominant ant species (Ar and Pf) near and far from F. subsericea nests.

\begin{tabular}{cccccc}
\hline Response Variable & Taxa & Test & $\boldsymbol{n}$ & Test Statistic & $p$ \\
\hline Colony size & A.rudis & Wilcoxon Rank Sums & 10 & $\mathrm{Z}=0.12$ & 0.91 \\
Colony size & N. faisonensis & Two-sample -test & 11.53 & t-Ratio $=-0.21$ & 0.42 \\
Colony productivity & A. rudis & Wilcoxon Rank Sums & 10 & $\mathrm{Z}=-0.46$ & 0.64 \\
Colony productivity & N. faisonensis & Wilcoxon Rank Sums & 11.61 & $\mathrm{Z}=-1.74$ & 0.08 \\
\hline
\end{tabular}

3.4. Is Resource Exploitation by Non-Dominant Ants Negatively Influenced by Proximity to a Dominant Ant Colony?

The mean number of $F$. subsericea workers recorded at baits was $3 \times$ higher near $(\leq 1 \mathrm{~m})$ than far $(\geq 5 \mathrm{~m}$ ) from the focal nest (Table 4, Figure 3a). During the day, the number of workers of non-dominant species was $50 \%$ lower at baits near than far from focal $F$. subsericea nests but the richness of non-dominant species did not differ between near and far baits (Table 4 ). There were $4 \times$ fewer A. rudis workers on baits near than far from F. subsericea nests during the day (Table 4, Figure 3a). However, there was no difference in the number of $N$. faisonensis (Table 4, Figure 3a) or M. punctiventris (Table 4, Figure 3a) workers on baits near and far from F. subsericea nests during the day. 
Table 4. Difference in resource use of dominant (Fs) and non-dominant ant species near and far from nests of F. subsericea.

\begin{tabular}{cccccc}
\hline Source of Variation & Response Variable & Taxa & Test & Test Statistic & $p$ \\
\hline Distance (day) & Species richness & all & Paired $t$-test & t-Ratio $=-1.20$ & 0.13 \\
Distance (day) & Worker abundance & all & Wilcoxon Sign-Rank & Z $=23.00$ & $0.04^{*}$ \\
Distance (day) & Worker abundance & Ar & Wilcoxon Sign-Rank & Z $=27.50$ & $0.01^{*}$ \\
Distance (day) & Worker abundance & Fs & Wilcoxon Sign-Rank & Z $=-39.00$ & $<0.0001^{* *}$ \\
Distance (day) & Worker abundance & $\mathrm{M}$ & Wilcoxon Sign-Rank & Z $=-9.00$ & 0.13 \\
Distance (day) & Worker abundance & Nf & Wilcoxon Sign-Rank & Z $=-2.00$ & 0.41 \\
Distance (night) & Species richness & all & Paired $t$-test & t-Ratio $=0.00$ & 1.00 \\
Distance (night) & Worker abundance & all & Wilcoxon Sign-Rank & Z $=-2.00$ & 0.46 \\
Distance (night) & Worker abundance & Ar & Wilcoxon Sign-Rank & Z $=-2.00$ & 0.55 \\
Distance (night) & Worker abundance & Fs & Wilcoxon Sign-Rank & NA & NA \\
Distance (night) & Worker abundance & M & Wilcoxon Sign-Rank & Z $=-1.50$ & 0.41 \\
Distance (night) & Worker abundance & Nf & Paired $t$-test & t-Ratio $=-2.36$ & $0.02 *$ \\
\hline
\end{tabular}

Differences are shown separately for day and night baiting trials. The table shows significant differences for parametric or non-parametric statistical tests, depending on the distribution of the data $\left({ }^{*} p<0.05,{ }^{* *} p<0.01\right)$. $\mathrm{Ar}=$ A. rudis $; \mathrm{Nf}=$ N. faisonensis $; \mathrm{Mp}=$ M. punctiventris.
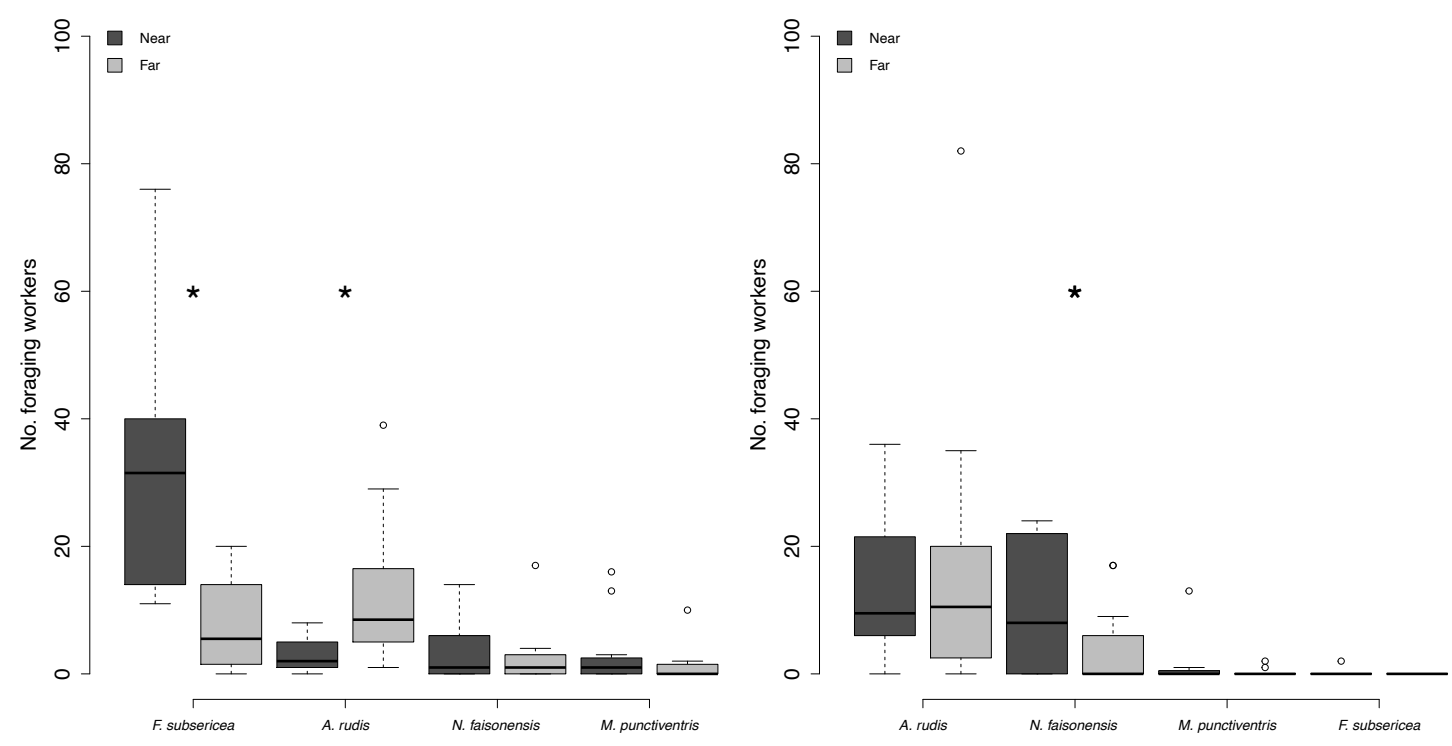

Figure 3. Mean number of workers of A. rudis, M. punctiventris and N. faisonensis recorded on baits near and far from focal nests of dominant F. subsericea (a) during the day and (b) at night. Asterisks indicate significant differences between near and far baits $(p<0.05)$.

In only one instance did we find F. subsericea workers foraging at night (i.e., one worker at one bait), suggesting that $F$. subsericea is largely diurnal, at least in this system. At night, there was no difference in the number of workers of non-dominant species (Table 4, Figure 3b), nor in the number of non-dominant species (Table 4, Figure 3b) on baits near and far from focal F. subsericea nests. Likewise, there was no difference in the number of $A$. rudis (Table 4, Figure 3b) or M. punctiventris workers (Table 4, Figure $3 \mathrm{~b}$ ) on baits near and far from F. subsericea nests. There were, however, $2 \times$ more N. faisonensis workers on baits near than far from F. subsericea nests at night (Table 4, Figure 3b).

\subsection{Are Temporal Patterns of Foraging Activity in Non-dominant Species Negatively Related to Those of the Dominant Species?}

There were higher numbers of workers of non-dominant species foraging on baits at night than during the day (mean difference $=-28.5 \pm 9.60$; Table 4; Figure 4a). Additionally, there were fewer species of non-dominant ants recorded on baits at night than during the day (mean difference $=1.33 \pm 0.36$; Table 4; Figure 4 b). There were $2 \times$ more A. rudis workers recorded on baits at night than during the day 
(mean difference $=-14.92 \pm 5.83$, Tables 5 and 6). The same trend was seen in $\mathrm{N}$. faisonensis, with $2 \times$ more workers on baits at night than during the day (mean difference $=-8.50 \pm 3.29$, Tables 5 and 6). There were $2 \times$ fewer $M$. punctiventris workers recorded on baits at night than during the day (mean difference $=-2.92 \pm 1.19$, Tables 5 and 6).

Table 5. Difference in the number of species and worker of non-dominant ants recorded on baits between the day and night (day-night). The table shows significant differences for parametric or non-parametric statistical tests, depending on the distribution of the data $\left({ }^{*} p<0.05,{ }^{* *} p<0.01\right.$ ).

\begin{tabular}{ccccc}
\hline Response Variable & Taxa & Test & Test Statistic & $p$ \\
\hline Species richness & all & $t$-test & $\mathrm{t}=3.75$ & $0.002^{* *}$ \\
Worker abundance & all & $t$-test & $\mathrm{t}=-2.94$ & $0.007^{* *}$ \\
Worker abundance & $\mathrm{Ar}$ & $t$-test & $\mathrm{t}=-2.56$ & $0.01^{*}$ \\
Worker abundance & $\mathrm{Fs}$ & $t$-test & $\mathrm{t}=5.57$ & $<0.0001^{* *}$ \\
Worker abundance & $\mathrm{M}$ & Wilcoxon Signed-Rank & $\mathrm{Z}=22.5$ & $0.002^{* *}$ \\
Worker abundance & $\mathrm{Nf}$ & $t$-test & $\mathrm{t}=-2.58$ & $0.01^{*}$ \\
\hline
\end{tabular}

Table 6. Mean number of workers $( \pm \mathrm{SE})$ recorded at baits during the day and at night.

\begin{tabular}{ccccc}
\hline \multirow{2}{*}{ Species } & \multicolumn{2}{c}{ Day } & \multicolumn{2}{c}{ Night } \\
\cline { 2 - 5 } & Mean & SE & Mean & SE \\
\hline Aphaenogaster rudis Enzmann & 7.67 & 1.95 & 15.13 & 3.6 \\
Camponotus americanus Mayr & 1 & 0.73 & 0.83 & 0.5 \\
Camponotus pennsylvanicus (DeGeer) & 0.38 & 0.25 & 1.38 & 0.76 \\
Formica subsericea Say & 20.25 & 3.97 & 0.08 & 0.08 \\
Lasius alienus (Förster) & 2.29 & 2.25 & 2.33 & 2.16 \\
Myrmica punctiventris Roger & 2.21 & 0.88 & 0.75 & 0.54 \\
Nylanderia faisonensis (Forel) & 3.08 & 0.97 & 7.33 & 1.88 \\
Prenolepis imparis (Say) & 0 & 0 & 4.25 & 4.25 \\
Temnothorax curvispinosus (Mayr) & 0.63 & 0.22 & 0 & 0 \\
Temnothorax longispinosus (Roger) & 0.63 & 0.28 & 0 & 0 \\
\hline
\end{tabular}
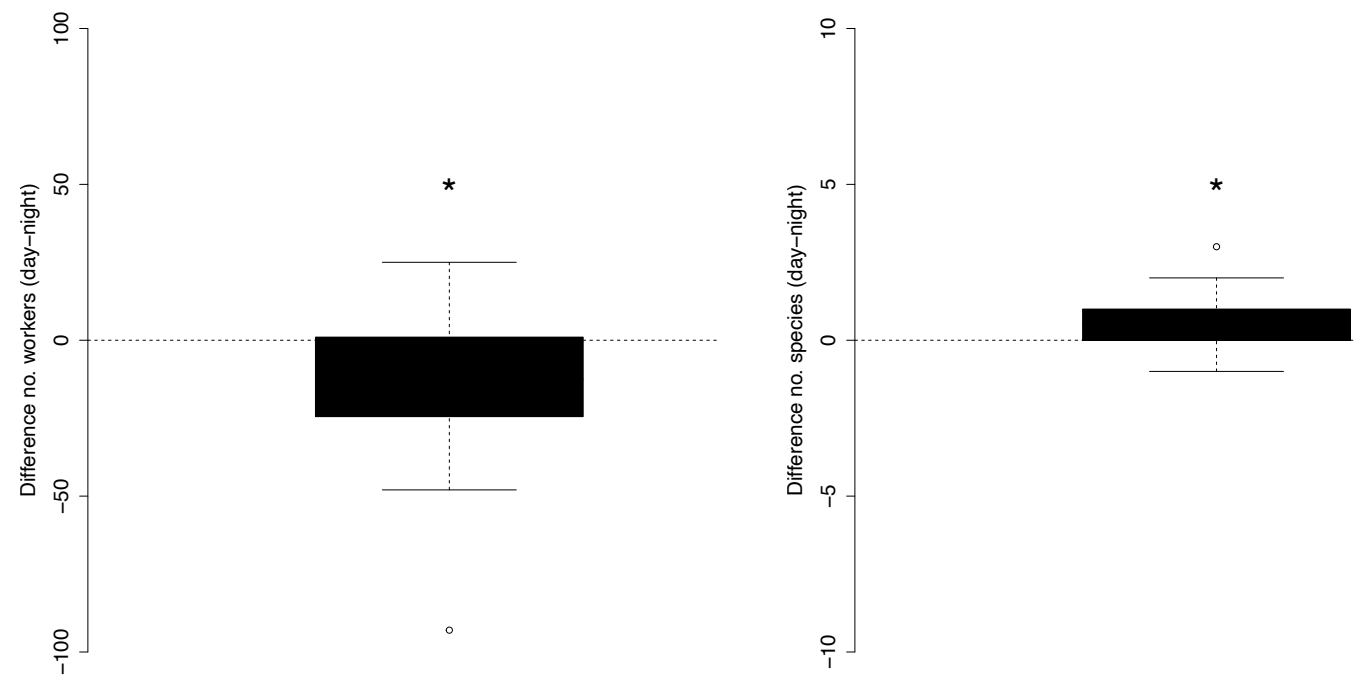

Figure 4. Mean difference in the (a) number of workers and (b) species richness of non-dominant ant species recorded on baits during day and night. Asterisk indicates a significant difference in foraging activity between day and night $(p<0.01)$.

\section{Discussion}

Increases in the abundance of one species are often associated with decreases in abundance and richness of other species it competes with [2,3]. If these patterns resulted from competitive exclusion, 
one would expect negative impacts of the dominant species on the subordinate species to trickle up and down organization levels. Here, we found only weak support that the abundance of dominant F. subsericea ants was related to the richness of non-dominant ant species across sites $[4,5,18,19,44]$. However, the shape of that relationship was sensitive to the inclusion/exclusion of a highly influential observation. Moreover, except for a few exceptions, population-, individual- and worker level variables such as abundance, productivity and foraging behavior did not match the predictions of competitive exclusion and its impact on diversity maintenance. It might thus be that competitive interactions do not lead to the exclusion of non-dominant ants [69,70].

One mechanism by which dominant ant species might exert community-level influence on non-dominant species is by reducing the amount of resources available in the system (e.g., dominance-impoverishment-rule [71] but see Reference [19]. Although in our system dominant ant species do not appear to affect population-level impact on the abundance of non-dominant ants, they could nevertheless have individual-level effects. Specifically, by interfering with resource use and/or resource acquisition by non-dominant species [29,32], dominant species may negatively affect the size, productivity and fitness of colonies of non-dominant ants [26]. For example, in Finnish ant assemblages colonies of non-dominant ants found inside the territory of dominant Formica tend to be smaller than those found outside dominant Formica territories [26]. However, proximity to a F. subsericea nest, the dominant ant species at our study sites, did not affect colony size in two of the most common non-dominant ant species (A. rudis and N. faisonensis). Gibb and Hochuli (2004) experimentally excluded dominant Iridomyrmex purpureus and found only congeneric species to benefit from competitive release, suggesting that dominant species might have greater effects on closely related species than they do on those that are distantly related [11]. In our system, F. subsericea was the only representative of the genus and the principal competitors are quite smaller in size suggesting perhaps lower overlap in resource use under natural conditions.

While we did not observe any effect of dominant ants on colony size, we found evidence of positive effects on another individual-level variable. Colony productivity of $N$. fasionensis tended to be higher in colonies near F. subsericea nests relative to colonies that were far from these nests (note that $p=0.06$ ). Thus, contrary to our expectations, dominant ants did not negatively affect the size and productivity of subordinate colonies of these common species and may actually be associated with enhanced productivity in one species-N. fasionensis. Such positive effects of a large-bodied dominant species on small-bodied non-dominant species can arise when the indirect effects of competition outweigh the direct effects [72]. Davidson [73] who was working with harvester ants in desert systems showed that despite dietary overlap between a large species (Pogonomyrmex rugosus) and a small species (Pheidole xerophila), the large species facilitated the small species indirectly by suppressing populations of an intermediate-size species (Pogonomyrmex desertorum). It may thus be the case that in our system F. subsericea (large size) suppress populations of $A$. rudis (medium size), thereby facilitating N. fasionensis (small). Apparent facilitation might thus be at play [73].

In sum, we did not find strong community, population or individual-level evidence that dominant F. subsericea negatively affects non-dominant ants. We did, however, limit our analyses to a subsample of the most common species in the assemblage. One possibility is that dominant ants do not affect the resource use of all of the non-dominant species equally. For example, although $F$. subsericea interferes with foraging and resource use by A. rudis, two non-dominant ant species (N. faisonensis and M. punctiventris) did not exhibit lower resource use near F. subsericea nests relative to far. Thus, while $F$. subsericea was dominant over $N$. faisonensis and M. punctiventris in aggressive encounters, it did not decrease the resource use of these species at transient food items. However, we did not estimate the amount of time spent at resources or the rate at which resources were removed, which might be more accurate estimates of resource use by ants [74]. Nevertheless, the lower foraging among A. rudis observed near than far from $F$. subsericea nests did not translate to reduced colony size or productivity. Herbers [30] noted that temperate forest ant assemblages can be limited by the availability of nest sites, 
rather than food resources. Thus, the benefit of nesting in a suitable patch might outweigh the cost incurred by increased competition for food resources when nesting near a dominant ant nest.

The seemingly weak influence of competitive interactions with dominant ants on non-dominant ants at the community, population and individual level suggests a need for further examination of the life strategies that allow these species to coexist. Previous work in southeastern temperate forests of USA showed that the structure of these ant communities are highly influenced by temperature filtering; from regional to micro-scale $[43,75,76]$. Moreover, in these ant communities, trade-off between thermal tolerance and competitive ability provide a mechanism by which species prevent competitive exclusion. Non-dominant species indeed appear to forage at lower temperatures exploiting shaded parts of the forest floors while dominant ants appear to dominate open canopy habitats where sunlight reach the forest floor [61]. Results from the present study further demonstrate that non-dominant ant species can forage during both the night and the day whereas dominant Formica only forage during the day, which suggests a strategy to avoid interference competition $[59,77,78]$. In our system, interspecific overlap in seasonal activity is high, with most species reaching peak foraging activity in the warmest months of the year [79]. However, our results suggest that on a daily basis, variation in activity levels may be important for coexistence. While there were more species active during the day when F. subsericea forages than at night when F. subsericea is not active, there were more workers of non-dominant ants foraging at night. Thus, colonies of some non-dominant ants might send more workers out to forage at night than during the day to avoid aggressive encounters with dominant species, a phenomenon that has been previously documented with dominant Formica in Finnish forest ant assemblages [28].

Our results suggest that, although dominant ants might sometimes play an important role in structuring ant communities, we find very little evidence of the negative effects of the dominant species in this system across levels of organizations. Note however that whereas much of the previous work on dominant species focused on extremely abundant and aggressive ant species, the dominance of our focal species here is more relative and less absolute. Moreover, our study, as well as most studies that have examined richness-dominance relationship in ants, are observational, which limits our ability to infer causality. Nevertheless, we conclude that although competition evidently occurs in ant communities, other coexistence mechanisms in place may be sufficient to prevent local extinctions [69]. Moreover, there are multiple explanations for the commonly observed hump-shaped relationship between the abundance of dominant ants and species richness among ant communities. Variation in the abiotic environment alone could be driving this widespread pattern if the fitness of non-dominant and dominant species peak at different places along micro-environmental gradients. Further, our results indicate that some non-dominant species may actually benefit from nesting in the vicinity of dominant ant species [80], as was evidenced by higher productivity and nocturnal foraging in a non-dominant species near than far from dominant ant nests. Disentangling the direct and indirect effects of dominant ants on non-dominant ants likely requires further field experiments that manipulate the density of dominant species (rather than just presence/absence) to assess colony-level as well as population- and community-level responses of non-dominant ants (e.g., References [22,23,81-83]).

Author Contributions: Conceptualization, J.-P.L., K.L.S. and N.J.S.; methodology, J-P.L. and N.J.S.; validation, J.-P.L., K.L.S. and N.J.S.; formal analysis, J.-P.L.; investigation, J.-P.L.; resources, J.-P.L. and N.J.S.; data curation, J.-P.L.; writing—original draft preparation, J.-P.L. and N.J.S.; writing—review and editing, J.-P.L., K.L.S. and N.J.S.; visualization, J.-P.L.; supervision, N.J.S.; project administration, J.-P.L. and N.J.S.; funding acquisition, N.J.S. All authors have read and agreed to the published version of the manuscript.

Funding: This research was funded by the U.S. Department of Energy PER award (DEFG02-08ER64510) and a National Science Foundation Dimensions of Biodiversity grant (NSF-1136703). Additional support was granted to J-P.L. from the Department of Ecology and Evolutionary Biology at the University of Tennessee, an NSERC-PGS doctoral scholarship and a NSF-DDIG. 
Acknowledgments: We thank Alan Andersen, Tara Sackett, Mariano Rodriguez-Cabal, David Fowler and three anonymous reviewers for making comments that greatly improved the manuscript, Noa Davidai and Benoit Guenard for help in the field and Gabriel Munoz for help with the visuals. This study was permitted by and enhanced through collaboration with the Great Smoky Mountains National Park.

Conflicts of Interest: The authors declare no conflict of interest. The funders had no role in the design of the study; in the collection, analyses or interpretation of data; in the writing of the manuscript or in the decision to publish the results.

\section{References}

1. Grime, J.P. Colonization, Succession and Stability; Blackwell: Oxford, UK, 1984.

2. Janzen, D.H. Herbivores and the Number of Tree Species in Tropical Forests. Am. Nat. 1970, 104, 501-528. [CrossRef]

3. Connell, J.H. On the role of natural enemies in preventing competitive exclusion in some marine animals and in rain forest trees. In Dynamics of Population; Den Boer, P.J., Gradwell, G.R., Eds.; Pudoc: Wageningen, The Netherlands, 1970.

4. Parr, C.L. Dominant ants can control assemblage species richness in a South African savanna. J. Anim. Ecol. 2008, 77, 1191-1198. [CrossRef] [PubMed]

5. Parr, C.L.; Sinclair, B.J.; Andersen, A.N.; Gaston, K.J.; Chown, S.L. Constraint and competition in assemblages: A cross-continental and modeling approach for ants. Am. Nat. 2005, 165, 481-494. [CrossRef] [PubMed]

6. Gotelli, N.J.; Arnett, A.E. Biogeographic effects of red fire ant invasion. Ecol. Lett. 2000, 3, 257-261. [CrossRef]

7. Holway, D.A. Effect of Argentina ant invasions on ground-dwelling arthropods in northern California riparian woodlands. Oecologia 1998, 116, 252-258. [CrossRef] [PubMed]

8. Human, K.G.; Gordon, D.M. Exploitation and interference competition between the invasive Argentine ant, Linepithema humile, and native ant species. Oecologia 1996, 105, 405-412. [CrossRef] [PubMed]

9. Porter, S.; Savignano, D. Invasion of Polygyne Fire Ants Decimates Native Ants and Disrupts Arthropod Community. Ecology 1990, 71, 2095-2106. [CrossRef]

10. Sanders, N.J.; Gotelli, N.J.; Heller, N.E.; Gordon, D.M. Community disassembly by an invasive species. Proc. Natl. Acad. Sci. USA 2003, 100, 2474-2477. [CrossRef]

11. Lessard, J.-P.; Fordyce, J.A.; Gotelli, N.J.; Sanders, N.J. Invasive ants alter the phylogenetic structure of ant communities. Ecology 2009, 90, 2664-2669. [CrossRef]

12. Sanders, N.J.; Crutsinger, G.M.; Dunn, R.R.; Majer, J.D.; Delabie, J.H.C. An ant mosaic revisited: Dominant ant species disassemble arboreal ant communities but co-occur randomly. Biotropica 2007, 39, $422-427$. [CrossRef]

13. Davidson, D.W.; Lessard, J.P.; Bernau, C.R.; Cook, S.C. The tropical ant mosaic in a primary Bornean rain forest. Biotropica 2007, 39, 468-475. [CrossRef]

14. Jackson, D.A. Ant Distribution Patterns in a Cameroonian Cocoa Plantation-Investigation of the Ant Mosaic Hypothesis. Oecologia 1984, 62, 318-324. [CrossRef] [PubMed]

15. Leston, D. Neotropical Ant Mosaic. Ann. Entomol. Soc. Am. 1978, 71, 649-653. [CrossRef]

16. Majer, J.D.; Delabie, J.H.C.; Smith, M.R.B. Arboreal Ant Community Patterns in Brazilian Cocoa Farms. Biotropica 1994, 26, 73-83. [CrossRef]

17. Adams, E.S. Territory Defense by the Ant Azteca-Trigona-Maintenance of an Arboreal Ant Mosaic. Oecologia 1994, 97, 202-208. [CrossRef]

18. Andersen, A.N. Regulation of Momentary Diversity by Dominant Species in Exceptionally Rich Ant Communities of the Australian Seasonal Tropics. Am. Nat. 1992, 140, 401-420. [CrossRef]

19. Sheard, J.K.; Nelson, A.S.; Berggreen, J.D.; Boulay, R.; Dunn, R.R.; Sanders, N.J. Testing trade-offs and the dominance-impoverishment rule among ant communities. J. Biogeogr. 2020, 47, 1899-1909. [CrossRef]

20. Arnan, X.; Andersen, A.N.; Gibb, H.; Parr, C.L.; Sanders, N.J.; Dunn, R.R.; Angulo, E.; Baccaro, F.B.; Bishop, T.R.; Boulay, R.; et al. Dominance-diversity relationships in ant communities differ with invasion. Glob. Chang. Biol. 2018, 24, 4614-4625. [CrossRef]

21. Gibb, H. Dominant meat ants affect only their specialist predator in an epigaeic arthropod community. Oecologia 2003, 136, 609-615. [CrossRef]

22. Gibb, H.; Hochuli, D.F. Removal experiment reveals limited effects of a behaviorally dominant species on ant assemblages. Ecology 2004, 85, 648-657. [CrossRef] 
23. Gibb, H.; Johansson, T. Field tests of interspecific competition in ant assemblages: Revisiting the dominant red wood ants. J. Anim. Ecol. 2011, 80, 548-557. [CrossRef] [PubMed]

24. Deslippe, R.J.; Savolainen, R. Mechanisms of Competition in a Guild of Formicine Ants. Oikos 1995, 72, 67-73. [CrossRef]

25. Herbers, J.M.; Banschbach, V.S. Food supply and reproductive allocation in forest ants: Repeated experiments give different results. Oikos 1998, 83, 145-151. [CrossRef]

26. Savolainen, R. Colony Success of the Submissive Ant Formica-Fusca within Territories of the Dominant Formica-Polyctena. Ecol. Entomol. 1990, 15, 79-85. [CrossRef]

27. Savolainen, R. Interference by Wood Ant Influences Size Selection and Retrieval Rate of Prey by Formica-Fusca. Behav. Ecol. Sociobiol. 1991, 28, 1-7. [CrossRef]

28. Vepsalainen, K.; Savolainen, R. The Effect of Interference by Formicine Ants on the Foraging of Myrmica. J. Anim. Ecol. 1990, 59, 643-654. [CrossRef]

29. Fellers, J.H. Interference and Exploitation in a Guild of Woodland Ants. Ecology 1987, 68, 1466-1478. [CrossRef]

30. Herbers, J.M. Community Structure in North Temperate Ants-Temporal and Spatial Variation. Oecologia 1989, 81, 201-211. [CrossRef]

31. Savolainen, R.; Vepsalainen, K. A Competition Hierarchy among Boreal Ants-Impact on Resource Partitioning and Community Structure. Oikos 1988, 51, 135-155. [CrossRef]

32. Savolainen, R.; Vepsalainen, K. Niche Differentiation of Ant Species within Territories of the Wood Ant Formica Polyctena. Oikos 1989, 56, 3-16. [CrossRef]

33. Savolainen, R.; Vepsalainen, K.; Wuorenrinne, H. Ant Assemblages in the Taiga Biome-Testing the Role of Territorial Wood Ants. Oecologia 1989, 81, 481-486. [CrossRef] [PubMed]

34. Tilman, D. The Importance of the Mechanisms of Interspecific Competition. Am. Nat. 1987, 129, 769-774. [CrossRef]

35. Cerdá, X.; Retana, J.; Manzaneda, A. The role of competition by dominants and temperature in the foraging of subordinate species in Mediterranean ant communities. Oecologia 1998, 117, 404-412. [CrossRef]

36. Holway, D.A. Competitive mechanisms underlying the displacement of native ants by the invasive Argentine ant. Ecology 1999, 80, 238-251. [CrossRef]

37. Erôs, K.; Maák, I.; Markó, B.; Babik, H.; Ślipiński, P.; Nicoară, R.; Czechowski, W. Competitive pressure by territorials promotes the utilization of unusual food source by subordinate ants in temperate European woodlands. Ethol. Ecol. Evol. 2020, 32, 457-465. [CrossRef]

38. Law, S.J.; Parr, C. Numerically dominant species drive patterns in resource use along a vertical gradient in tropical ant assemblages. Biotropica 2020, 52, 101-112. [CrossRef]

39. Andersen, A.N. Not enough niches: Non-equilibrial processes promoting species coexistence in diverse ant communities. Austral. Ecol. 2008, 33, 211-220. [CrossRef]

40. Francoeur, A. Révision taxonomique des espèces néarctiques du groupe fusca, genre Formica (Formicidae, Hymenoptera). Mem. Soc. Ent. Québec 1973, 3, 1-316.

41. Fellers, J.H. Daily and Seasonal Activity in Woodland Ants. Oecologia 1989, 78, 69-76. [CrossRef]

42. Lessard, J.-P.; Dunn, R.R.; Parker, C.R.; Sanders, N.J. Rarity and Diversity in Forest Ant Assemblages of Great Smoky Mountains National Park. Southeast. Nat. 2007, 6, 215-228. [CrossRef]

43. Lessard, J.-P.; Sackett, T.E.; Reynolds, W.N.; Fowler, D.A.; Sanders, N.J. Determinants of the detrital arthropod community structure: The effects of temperature and resources along an environmental gradient. Oikos 2011, 120, 333-343. [CrossRef]

44. Sanders, N.J.; Lessard, J.-P.; Fitzpatrick, M.C.; Dunn, R.R. Temperature, but not productivity or geometry, predicts elevational diversity gradients in ants across spatial grains. Glob. Ecol. Biogeogr. 2007, 16, 640-649. [CrossRef]

45. Cammell, M.E.; Way, M.J.; Paiva, M.R. Diversity and structure of ant communities associated with oak, pine, eucalyptus and arable habitats in Portugal. Insectes Sociaux 1996, 43, 37-46. [CrossRef]

46. Stuble, K.; Kirkman, L.K.; Carroll, C.R. Patterns of abundance of fire ants and native ants in a native ecosystem. Ecol. Entomol. 2009, 34, 520-526. [CrossRef]

47. LeBrun, E.; Feener, D. When trade-offs interact: Balance of terror enforces dominance discovery trade-off in a local ant assemblage. J. Anim. Ecol. 2007, 76, 58-64. [CrossRef] 
48. Ellison, A.M.; Record, S.; Arguello, A.; Gotelli, N.J. Rapid inventory of the ant assemblage in a temperate hardwood forest: Species composition and assessment of sampling methods. Environ. Entomol. 2007, 36, 766-775. [CrossRef]

49. Longino, J.T.; Colwell, R.K. Biodiversity assessment using structured inventory: Capturing the ant fauna of a tropical rain forest. Ecol. Appl. 1997, 7, 1263-1277. [CrossRef]

50. King, J.R. Size-abundance relationships in Florida ant communities reveal how ants break the energetic equivalence rule. Ecol. Entomol. 2010, 35, 287-298. [CrossRef]

51. Gotelli, N.J.; Ellison, A.M. Biogeography at a regional scale: Determinants of ant species density in new england bogs and forests. Ecology 2002, 83, 1604-1609. [CrossRef]

52. Lubertazzi, D. The Biology and Natural History of Aphaenogaster rudis. Psyche 2012, 2012, 752815. [CrossRef]

53. Nuhn, T.P.; Wright, C.G.; Farrier, M.H. Notes on the biology of the ant Paratrechina faisonensis (Hymenoptera: Formicidae). J. Elisha Mitchell Sci. Soc. 1992, 108, 11-18.

54. Kaspari, M. Testing resource-based models of patchiness in four Neotropical litter ant assemblages. Oikos 1996, 76, 443-454. [CrossRef]

55. McGlynn, T.P.; Hoover, J.R.; Jasper, G.S.; Kelly, M.S.; Polis, A.M.; Spangler, C.M.; Watson, B.J. Resource heterogeneity affects demography of the Costa Rican ant Aphaenogaster araneoides. J. Trop. Ecol. 2002, 18, 231-244. [CrossRef]

56. Beugnon, G.; Fourcassie, V. How Do Red Wood Ants Orient during Diurnal and Nocturnal Foraging in a 3 Dimensional System. 2. Field Experiments. Insectes Sociaux 1988, 35, 106-124. [CrossRef]

57. Hillery, A.E.; Fell, R.D. Chemistry and Behavioral significance of rectal and accessory gland contents in Camponotus pennsylvanicus (Hymenoptera: Formicidae). Ann. Entomol. Soc. Am. 2000, 93, 1294-1299. [CrossRef]

58. Torres, J.A.; Snelling, R.R.; Jones, T.H. Distribution, ecology and behavior of Anochetus kempfi (Hymenoptera: Formicidae) and description of the sexual forms. Sociobiology 2000, 36, 505-516.

59. Retana, J.; Cerdá, X. Patterns of diversity and composition of Mediterranean ground ant communities tracking spatial and temporal variability in the thermal environment. Oecologia 2000, 123, 436-444. [CrossRef]

60. Stuble, K.L.; Jurić, I.; Cerdá, X.; Sanders, N.J. Dominance hierarchies are a dominant paradigm in ant ecology (Hymenoptera: Formicidae), but should they be? And what is a dominance hierarchy anyways? Myrmecol. News 2017, 24, 71-81. [CrossRef]

61. Lessard, J.P.; Dunn, R.R.; Sanders, N.J. Temperature-mediated coexistence in forest ant communities. Insectes Sociaux 2009, 56, 149-156. [CrossRef]

62. Tschinkel, W.R.; Hess, C.A. Arboreal ant community of a pine forest in northern Florida. Ann. Entomol. Soc. Am. 1999, 92, 63-70. [CrossRef]

63. Vepsalainen, K.; Pisarski, B. Assembly of Island Ant Communities. Ann. Zool. Fenn. 1982, 19, 327-335.

64. Colley, W.N. Colley's Bias Free College Football Ranking Method: The Colley Matrix Explained. Available online: http://www.colleyrankings.com/matrate.pdf (accessed on 1 May 2009).

65. Longino, J.T.; Coddington, J.; Colwell, R.K. The ant fauna of a tropical rain forest: Estimating species richness three different ways. Ecology 2002, 83, 689-702. [CrossRef]

66. Kaspari, M.; Weiser, M.D. The size-grain hypothesis and interspecific scaling in ants. Funct. Ecol. 1999, 13, 530-538. [CrossRef]

67. Geraghty, M.J.; Dunn, R.R.; Sanders, N.J. Body size, colony size, and range size in ants (Hymenoptera: Formicidae): Are patterns along elevational and latitudinal gradients consistent with Bergmann's Rule? Myrmecol. News 2007, 10, 51-58.

68. Gotelli, N.J.; Ellison, A.M. A Primer of Ecological Statistics; Sinauer Associates, INC.: Sunderlan, MA, USA, 2004.

69. Chesson, P. Mechanisms of Maintenance of Species Diversity. Annu. Rev. Ecol. Syst. 2000, 31, 343-366. [CrossRef]

70. Chesson, P. Updates on mechanisms of maintenance of species diversity. J. Ecol. 2018, 106, 1773-1794. [CrossRef]

71. Hölldobler, B.; Wilson, E. The Ants; Belknap: Cambridge, MA, USA, 1990.

72. Davidson, D.W. Some Consequences of Diffuse Competition in a Desert Ant Community. Am. Nat. 1980, 116, 92-105. [CrossRef]

73. Davidson, D.W. An Experimental Study of Diffuse Competition in Harvester Ants. Am. Nat. 1985, 125, 500-506. [CrossRef] 
74. Jeanne, R.L. A Latitudinal Gradient in Rates of Ant Predation. Ecology 1979, 60, 1211-1224. [CrossRef]

75. Fowler, D.; Lessard, J.-P.; Sanders, N.J. Niche filtering rather than partitioning shapes the structure of temperate forest ant communities. J. Anim. Ecol. 2014, 83, 943-952. [CrossRef]

76. Lessard, J.-P.; Borregaard, M.K.; Fordyce, J.A.; Rahbek, C.; Weiser, M.D.; Dunn, R.R.; Sanders, N.J. Strong influence of regional species pools on continent-wide structuring of local communities. Proc. R. Soc. B Biol. Sci. 2012, 279, 266-274. [CrossRef]

77. Stuble, K.L.; Rodriguez-Cabal, M.A.; McCormick, G.L.; Jurić, I.; Dunn, R.R.; Sanders, N.J. Tradeoffs, competition, and coexistence in eastern deciduous forest ant communities. Oecologia 2013, 171, 981-992. [CrossRef] [PubMed]

78. Albrecht, M.; Gotelli, N.J. Spatial and temporal niche partitioning in grassland ants. Oecologia 2001, 126, 134-141. [CrossRef]

79. Dunn, R.R.; Parker, C.R.; Sanders, N.J. Temporal patterns of diversity: Assessing the biotic and abiotic controls on ant assemblages. Biol. J. Linn. Soc. 2007, 91, 191-201. [CrossRef]

80. Cerdá, X.; Arnan, X.; Retana, J. Is competition a significant hallmark of ant (Hymenoptera: Formicidae) ecology? Myrmecol. News 2013, 18, 131-147.

81. LeBrun, E.G.; Tillberg, C.V.; Suarez, A.V.; Folgarait, P.J.; Smith, C.R.; Holway, D.A. An experimental study of competition between Fire Ants and Argentine Ants in their native range. Ecology 2007, 88, 63-75. [CrossRef]

82. Stuble, K.L.; Kirkman, L.K.; Carroll, C.R.; Sanders, N.J. Relative effects of disturbance on Red Imported Fire Ants and native ant apecies in a longleaf pine ecosystem. Conserv. Biol. 2011, 25, 618-622. [CrossRef]

83. Menke, S.B.; Fisher, R.N.; Jetz, W.; Holway, D.A. Biotic and abiotic controls of Argentine Ant invasion success at local and landscape scales. Ecology 2007, 88, 3164-3173. [CrossRef]

Publisher's Note: MDPI stays neutral with regard to jurisdictional claims in published maps and institutional affiliations. 